\title{
Inactivation of Bacillus cereus cells by atmospheric pressure dielectric barrier discharge (DBD) plasma conditions
}

\author{
Pandu Merum ${ }^{1, a}$, Yuchuan Chu ${ }^{1, b}$, Feng Shi ${ }^{1, \mathrm{c}}$ and Yong Cao ${ }^{1, d,{ }^{*}}$ \\ ${ }^{1}$ School of mechanical engineering and automation, Harbin institute of technology Shenzhen \\ graduate school, P.R. China \\ apandumerum@yahoo.com, bychuan.chu@hit.edu.cn, cshi.feng@hit.edu.cn, dyongc@hit.edu.cn
}

Keywords: dielectric barrier discharge plasma (DBD), Inactivation, Bacillus cereus bacteria, Reactive oxygen species (ROS).

Abstract. Bacillus cereus is a gram positive, rod shaped, and most abundant bacteria in the nature. In this paper, we intended to focus on the inactivation and morphological and physiological changes of the bacillus cereus with various time periods of atmospheric pressure dielectric barrier discharge (APDBD) plasma exposures. Inactivation, morpho-physiological changes were observed by scanning electron microscope (SEM) in untreated and plasma treated bacterial cells with different time intervals of plasma. Experimental results proven that argon (neutral) gas and radiation of the plasma play an important role in the inactivation of bacterial cells (B. cereus). By these results, very less time of plasma exposure is enough to inactivate the bacterial cells in any surfaces in the environments.

\section{Introduction}

Atmospheric pressure plasma is an emerging new technique in plasma science and technology [1] which attracts great importance and widely using in biomedical applications such as sterilization [2, 3], treatment of cancerous cells $[4,5]$, wound healing [6, 7], blood coagulation [8, 9] and dental treatments [10, 11, 12, 13] due to their low-temperature nature and reactive properties [14]. Atmospheric pressure plasma waves formed by energetic electrons, neutral gas and ions, which are present in the plasma waves [15]. The energetic electrons produce reactive radicals and ions through collisions with the background of neutral gas (argon), while the argon gas temperature remains at room temperature [15]. Many atmospheric pressure plasmas have been creating for various uses. Among them, atmospheric pressure dielectric barrier discharge (APDBD) plasma is one of the plasma. Interaction of atmospheric plasma (APDBD) with bacterial cells (Bacillus cereus), living tissues and cells still unclear due to the complexity of atmospheric plasma and biological systems [16]. Usually, plasma has a strong ability feature to inactivate the bacteria in the nature [17]. There are very few researchers reported on the effects of atmospheric plasmas (APDBD) on bacterial cells [18, 19]. With this background, we conducted experiments for identification of plasma effects on Bacillus cereus bacterial cells once exposed to atmospheric plasma (APDBD). In addition, we also used scanning electron microscope (SEM) to investigate the bacterial cell morphological (abnormal) changes from microbial cells (Bacillus cereus) under various plasma conditions.

\section{Materials and Methods}

Bacterial strain and growth conditions: We used bacillus cereus as an experiment bacteria brought from China General Microbiological Culture Collection Center (CGMCC). The primary culture of bacillus cereus was cultivated in regular bases for every 24 hours on LB broth and then streaked on agar plates and incubated at $30\left[{ }^{\circ} \mathrm{C}\right]$ for overnight. After incubation, isolated single colony for inoculation into fresh $50[\mathrm{ml}]$ of liquid LB medium in a $100[\mathrm{ml}]$ clonical flask from overnight agar plate. The clonical flask was covered with aluminum foil and incubated at $30\left[{ }^{\circ} \mathrm{C}\right]$, at $180[\mathrm{rpm}]$ on incubator and shaker. Harvested bacterial cells after 12 hours and prepare the inoculum for further experiments. Then, $1 \mathrm{ml}$ of culture was used for centrifuged $(5[\mathrm{~min}], 10,000[\mathrm{~g}])$ and rinsed thrice with PBS solution as well with water, resuspended in $2 \mathrm{ml}$ of LB broth and diluted to a working 
concentrations. Then aliquots of bacillus sample were used for the plasma treatment, where samples were chemically fixed with the $4 \%$ concentration of formaldehyde and glutaraldehyde for $30 \mathrm{~min}$. Later, bacillus samples were then centrifuged (5000[g rpm]), supernatant was removed, and pellet resuspended in $1 \mathrm{ml}$ of PBS solution for thrice and then three times rinsed with double distilled water. For the sequential dehydrating steps through the organic solvent (Isopropanol) concentrations (30, 50, $60,70,80,90,100,100 \%$ [Vol/Vol] $)$ and transferred to plasma device.

Plasma device, parameters and conditions: APDBD plasma generating electrode protected with quartz tube and used for non-thermal atmospheric pressure dielectric barrier discharge (APDBD) plasma generated in a normal room condition. The device was designed at the laboratory of Harbin institute of technology, Shenzhen graduate School, SHENZHEN, china. The APDBD device was set at 6.8-7.0 [W] and $10[\mathrm{KHz}]$ plasma frequency used (51/min) for the experiment, bacterial cells were directly exposed to plasma. The distance between bacteria sample and electrode is $4[\mathrm{~cm}]$, depends on the plasma, irradiation time, and voltage. Argon gas was used for this experiment, and the argon plasma was created at atmospheric pressure.

Microscope analysis: $1[\mathrm{ml}]$ of overnight culture of bacillus cereus was separated under laminar hood. Bacillus cells collected at the late growth phase of bacteria and sample was prepared further for critical point drying. Twenty minutes after reaching the critical point, the pressure was released gradually, resulting in a dry sample surrounded by $\mathrm{CO}_{2}$ at ambient pressure and temperature. Dry samples were mounted on aluminum stubs $(15[\mathrm{~mm}])$ using double side adhesive carbon tape. The bacillus cells were imaged in a Scanning electron microscope (HITACHI S-4700) and SEM equipped with a cryo transfer system. Images were recorded in a format of 640X480 pixels.

Inactivation by plasma: For the inactivation test, the bacillus cereus was suspended in $0.9 \%$ phosphate buffered saline. The suspensions of experiment bacillus cells could dry at room temperature to dehydration for the one hour. The dehydrated bacillus cell samples placed in front of nozzle in the way of plasma. The bacillus cells exposed to the various plasma for $0,5,10,15,20,25$ and 30 [seconds]. After plasma treatment, the irradiated each aliquoted bacillus sample was transferred into a $1 \mathrm{ml}$ of $0.9 \%$ saline, and shaken for $1 \mathrm{~min}$. The bacillus bacteria in the saline were spread over on LB plate. The number of colonies was counted (Table 1) after 24 hours of incubation at $30\left[{ }^{\circ} \mathrm{C}\right]$ from untreated and treated bacillus cereus cells.

\begin{tabular}{|l|l|l|l|l|l|l|l|}
\hline Name of the species & $0 \mathrm{~s}$ & $5 \mathrm{~s}$ & $10 \mathrm{~s}$ & $15 \mathrm{~s}$ & $20 \mathrm{~s}$ & $25 \mathrm{~s}$ & $30 \mathrm{~s}$ \\
\hline Bacillus cereus & 355 & 296 & 264 & 236 & 168 & 135 & 91 \\
\hline
\end{tabular}

Table 1: Number of colonies (CFU) from different plasma treated bacillus cereus bacteria.

\section{Results and Discussion}

To investigate the effects of atmospheric plasma on the bacillus bacteria. Generally, plasma waves affect the growth of bacteria that depends on the frequency of the irradiation and the total energy absorbed by bacteria. When plasma waves were applied at $2.45[\mathrm{GHz}]$ frequency with high energy and for a long period of time, their thermal effect is most dominant and kills the bacillus bacterial cells. But, in sometimes, bacterial cells were exposed to plasma at low-temperatures than thermal destruction. Various morphological and physiological changes or detectable damages were observed on the cell wall of treated bacteria but not in untreated bacteria [Fig. $1 \mathrm{a}-\mathrm{g}$ ]. These damage effects were caused by reactive oxygen species (ROS), and structural disarrangements of the bacterial cell membrane, which leads to the emergence of pores. Large membrane pores causes leakage of important cytoplasm (intracellular molecules) come out of the bacillus bacterial cells, which may leads to inactivation and bacterial cell death. Fig. 1 [a-g] shows that cells of bacterial cells were heavily damaged due to irradiated to the plasma, to the point (Fig. 1g) where cell membrane integrity was largely lost and their cytoplasm was out of bacillus cells. Besides, Fig. [1a] shows that no morphological and physiological 
changes exhibited/observed in untreated bacillus cells. These results suggested that the effects of atmospheric pressure plasma on cell morphology and physiology of bacteria. It indicates that before cell death or inactivation takes place, normal bacteria cell functioning can be altered by exposure to plasma. Sometimes, these changes are reversible, cause irreversible damage or mutation to the bacterial cells or leads to the cellular death. In addition, the morphological and physiological effects of plasma exposure differed between the irradiated bacterial cells and control cells. Membrane integrity of bacteria was severely compromised because of plasma treatment.

a) Untreated cells

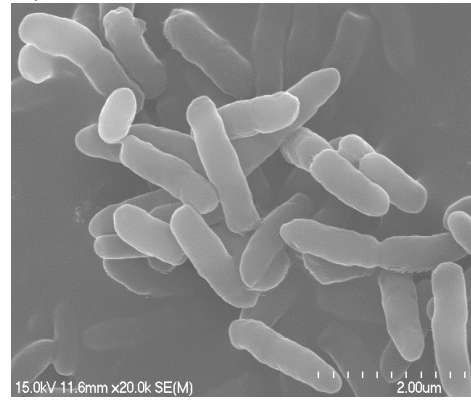

d) 15-seconds exposure

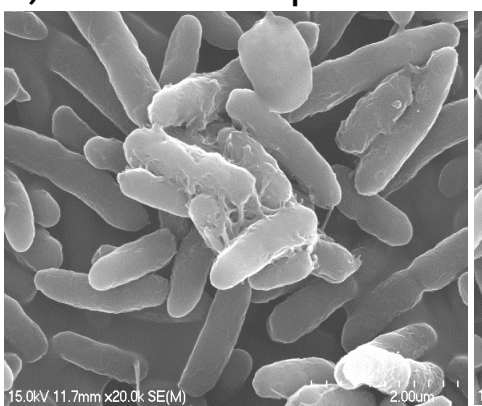

g) 30-seconds exposure

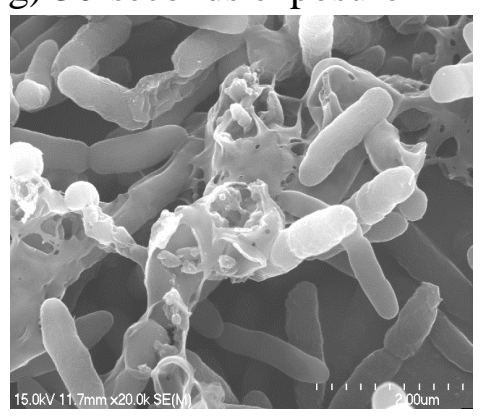

b) 5-seconds exposure

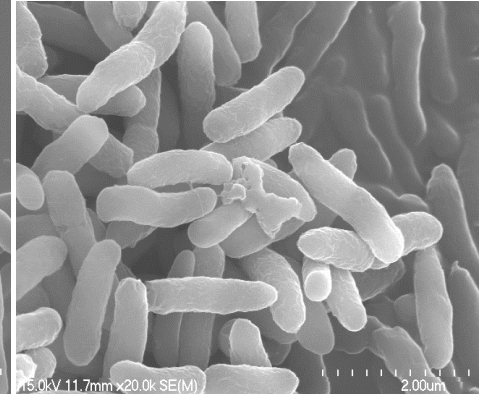

e) 20-seconds exposure

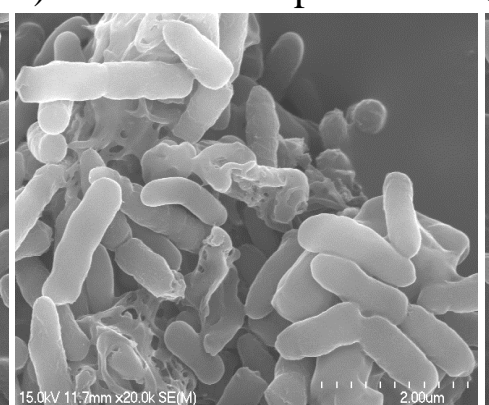

c) 10-seconds exposure

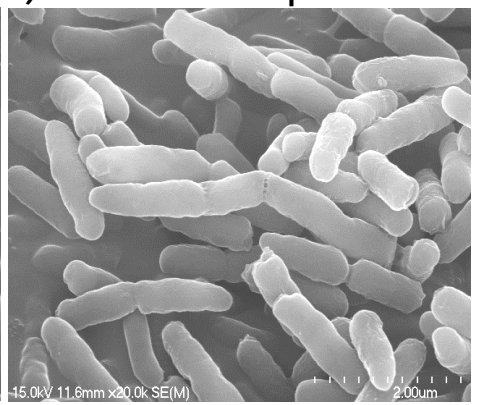

f) 25-seconds exposure

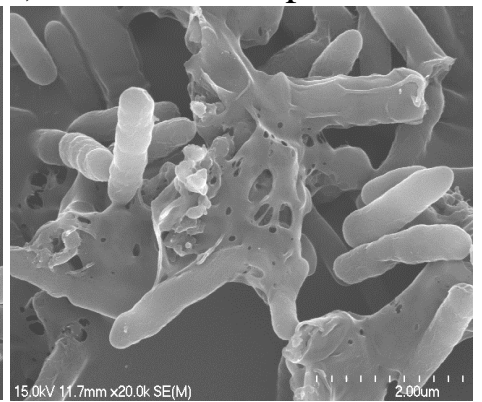

Fig. 1: Scanning electron microscope images of gram- positive bacteria Bacillus cereus; a) Untreated bacillus cereus cells, b-g) bacillus cereus cells.

\section{Conclusions}

Many atmospheric plasmas have been proven to be effective in an inactivation's of infected bacterial species. Our experimental bacterial [Bacillus cereus] cells are very smaller than other living cells, tissues and have less surface to treat with plasma. Based on our results were revealed that the less time of irradiation of plasma is enough to decontaminate and structural changes were also occurred with the large quantity of bacterial cells with atmospheric plasma.

\section{Acknowledgements}

The work described in this paper was supported by a grant from Shenzhen Technology Project (Project No. JCYJ20160226201347750 and GJHZ20160226200952216). The financial support is gratefully acknowledged. 


\section{References}

[1] G. Fridman, G. Friedman, A. Gutsol, A. Shekhter, V. Vasilets and A. Friedman: Plasma Process. Polym. Vol. 5 (2008), p. 503

[2] M. Laroussi: 2005 Plasma Process. Polym. Vol 2 (2005), p. 391

[3] J. Ehlbeck, U. Schnabel, M. Polak, J. Winter, T. von Woedtke, R. Brandenburg, T. von dem Hagen and K. Weltmann: J. Phys. D: Appl. Phys. Vol. 44, 013002

[4] G. Fridman, A. Shereshevsky, M. Jost, A. Brooks, A. Fridman, A. Gutsol, V. Vasilets and G. Friedman: Plasma Chem. Plasma Process Vol. 27 (2007), p. 163

[5] W. Kim, K.-C. Woo, G.-C. Kim and K.-T. Kim: J. Phys. D: Appl. Phys. Vol. 44, 013001

[6] G. Lloyd, G. Friedman, S. Jafri, G. Schultz, A. Fridman and K. Harding: Plasma Process. Polym. Vol. 7 (2010), p. 194

[7] J. Heinlin, G. Morfill, M. Landthaler, W. Stolz, G. Isbary, J.L. Zimmermann, T. Shimizu and S. Karrer: J. Gem. Soc. Dermatol. Vol. 8 (2010), p. 968

[8] S. Kalghatgi, G. Fridman, M. Cooper, G. Nagaraj, M. Peddinghaus, M. Balasubramanian, V. Vasilets, A. Gutsol, A. Fridman and G. Friedman: IEEE Trans. Plasma Sci. Vol. 35 (2007), p. 1559

[9] S. Kuo, O. Tarasenko, J. Chang, S. Popovic, C. Chen, H. Fan, A. Scott, M. Lahiani, P. Alusta and J. Drake: New J. Phys. Vol. 11 (2009), Article ID 115016

[10] P. Sun, J. Pan, Y. Tian, N. Bai, H. Wu, L. Wang, C. Yu, J. Zhang, W. Zhu and K.H. Becker: IEEE Trans. Plasma Sci. Vol. 38 (2010), p. 1892

[11] C. Jiang, M.T. Chen, C. Schaudinn, A. Gorur, P.T. Vernier, J.W. Costerton, D.E. Jaramillo, P.P. Sedghizadeh and M.A. Gundersen: IEEE Trans. Plasma Sci. Vol. 37 (2009), p. 1190

[12] J. Park, S. Nam, H. Kwon, A. Mohamed, J. Lee and G. Kim: Int. Endod. J. Vol. 44 (2011), p.170

[13] G.Y. Park, S.J. Park, M.Y. Choi, I.G. Koo, J.H. Byun, J.W. Hong, J.Y. Sim, G.J. Collins and J.K. Lee: Plasma Sources Sci. Technol. Vol. 21(2012), Article ID 043001

[14] F. Iza, G.J. Kim, S.M. Lee, J.K. Lee, J.L. Walsh, Y.T. Zhang and M.G. Kong: Plasma Process. Polym. Vol. 5 (2008), p. 322

[15] C. Tendero, C. Tixier, P. Tristant, J. Desmaison and P. Leprince: Spectrochim. Acta B Vol. 61 (2006), p. 2

[16] D. Dobrynin, G. Fridman, G. Friedman and A. Fridman: New J. Phys. Vol. 11 (2009), 115020

[17] G. Fridman, A.D. Brooks, M. Balasubramanian, A. Fridman, A. Gutsol, V. Vasilets, H. Ayan and G. Friedman: Plasma Process. Polym. Vol. 4 (2007), p. 370

[18] A. Morris, G. McComns, T. Akan, W. Hynes, M. Laroussi and S. Tolle: Journal of Dental Hygiene Vol. 83 (2009), p. 55

[19] M. Mols, H. Mastwijk, M. Nierop Groot and T. Abee: J. Appl. Microbiol. Vol. 115 (2013), p. 689 